\title{
Pharmacy Students' Informal Use of Facebook and its Perceived Role in Pharmacy Education in Jordan
}

Zeinab Al Subeh, MPharm, PharmD, ${ }^{a}$ Feras Alali, PhD, ${ }^{b}$ Ahmed Awaisu, PhD ${ }^{b}$

${ }^{a}$ Faculty of Pharmacy, Jordan University of Science and Technology, Irbid, Jordan

${ }^{b}$ College of Pharmacy, Qatar University, Doha, Qatar

\begin{abstract}
Background: The use of social media, including Facebook ${ }^{\circledR}$, as a tool for learning is becoming increasingly important in health professional education programs, including pharmacy. However, information is lacking on the general perception of Facebook as a student-driven e-learning tool among pharmacy students.

Objectives: This study aimed to help pharmacy educators to understand how and why students use Facebook for academic purposes by evaluating undergraduate pharmacy students' informal use of Facebook ${ }^{\circledR}$ and their attitude toward using Facebook in professional pharmacy education in Jordan.

Method: This study was a cross-sectional web-based survey using a 38-item questionnaire that was developed through a multi-phase iterative process. The study targeted all professional year pharmacy students, both BSc and PharmD, at Jordan University of Science and Technology (JUST).

Results: Seven hundred twenty pharmacy students responded to the survey (response rate 31.3\%). The majority of the students (98.8\%) had personal accounts on Facebook ${ }^{\circ}$. Of this, the majority (82.4\%) reported that they unofficially used Facebook as a tool for studying or academic purposes beside other social purposes. Overall, the students demonstrated positive attitudes toward the use of Facebook in pharmacy education. About $78.6 \%$ of the respondents reported that Facebook contributed to their academic success. Furthermore, a substantial proportion of the students found Facebook ${ }^{\star}$ well accepted in teaching and learning environments (55.2\%) and believed that pharmacy schools should formally encourage students to use Facebook for academic purposes (54.1\%).

Conclusion: The findings of this study suggest that pharmacy students in Jordan frequently and highly utilize Facebook as an unofficial tool for communication, teaching and learning. In educational setting that lack formal e-learning platforms, Facebook ${ }^{\circledR}$ would be a good alternative. Pharmacy schools should make every effort to create an appropriate learning environment within Facebook ${ }^{\circledR}$ that could positively impact students' academic success. Interventions to improve attitudes toward social media e-professionalism should be in place before formally implementing Facebook and other social media platforms within the pharmacy academic environment.
\end{abstract}

Keywords: Facebook; social media; pharmacy students; pharmacy education; Middle East

\section{INTRODUCTION}

The widespread use of the Internet and advancements in information technology in this century allows most educational institutions to integrate online-based platforms and e-learning tools into their academic programs. The main purpose of these tools is to facilitate interactions and active learning between students and their instructors and among students themselves. The majority of modern health professional education programs offer e-learning systems to their students. ${ }^{1}$

Corresponding Author: Zeinab Al Subeh, MPharm, PharmD Lecturer, Clinical Pharmacy Department, Faculty of Pharmacy Jordan University of Science and Technology

P.O. Box3030, Irbid, Jordan

Email: zyalsubeh14@ph.just.edu.jo; zynabalsobh@gmail.com Tel: +962779467523; Fax: + 962 (0) 27095123
However, despite the continued efforts to improve the structure, design, and features of these e-learning tools, most students complain about major drawbacks that limit their use of these online tools. For instance, lack of interactivity; missing personal contact; poor structure; difficult communication with other students; technical problems; and the need for learning efforts, were the major limitations of e-learning tools that were reported by medical students at the Charité - Universitäts medizin Berlin, Germany. ${ }^{2}$ In addition, more professional, formal, and efficient e-learning resources such as Blackboard ${ }^{\circ}$ and Canvas ${ }^{\circledR}$, are not affordable nor supported for students in resource-constrained countries such as Jordan. The available Learning Management System (LMS) for students at Jordan University of Science and Technology (JUST) is a simple in-house developed system, which is not appealing to students and does not provide the platforms for students to freely interact and efficiently communicate. Students in Jordan have tried to selfinitiate their own e-learning environment through freely available social media tools, which could be efficient and cost- 
effective alternatives to other e-learning systems. Many universities take advantage of social media for student recruitment, promoting visibility and publicity. ${ }^{3}$ The use of social media tools in general, and Facebook in particular, have become useful and well-accepted approaches in teaching and learning. ${ }^{4,5}$

In pharmacy and other health care professional education programs, social media tools are becoming increasingly important. ${ }^{6}$ Facebook $^{\circ}$ is the most popular social media communication tool $^{7}$ with more than 1.94 billion monthly active users for March 2017. ${ }^{8}$ It provides students in various disciplines with a no cost platform to communicate, share educational resources and study materials, post news, conduct focused discussion sessions, and contact their classmates and teachers. ${ }^{9,10}$ Facebook ${ }^{\circ}$ facilitates the creation of an efficient learning environment by enabling different forms of communications using personal profiles, private or public groups, or public pages. ${ }^{11}$ These options are not provided by most available e-learning systems, making Facebook ${ }^{\circ}$ a good alternative as a formal and informal e-learning tool. ${ }^{12}$

There is growing evidence for the importance of Facebook ${ }^{\circ}$ implementation and utilization among students of healthrelated disciplines. For example, Pickering and Bickerdike found that Facebook ${ }^{\circ}$ could support medical students and enhance their performance in preparation for anatomy assessments. ${ }^{13}$ Pinilla and his colleagues noticed that posting on Facebook groups of undergraduate medical students reached its peak at the beginning of semesters and on the days before examinations. ${ }^{14}$ Various studies have reported the usefulness of Facebook ${ }^{\circ}$ for different academic purposes among pharmacy students. DiVall and Kirwin successfully used a course-linked Facebook ${ }^{\circ}$ page to facilitate the online discussion of the content of a Comprehensive Disease Management course among pharmacy students. ${ }^{15}$ Another study found that over half of pharmacy students supported the use of closed Facebook discussion groups in a pharmacotherapy course. ${ }^{16}$ Facebook $^{\circ}$ has also helped in exposing pharmacy students to relevant "real-world" issues that were related to the content of a pharmacy management and leadership course. ${ }^{17}$ In a recent study, Facebook ${ }^{\circ}$ was reported as an efficient tool to distribute information and advice about effective study techniques among pharmacy students. ${ }^{18}$ In addition, Facebook ${ }^{\circ}$ was found to be a good tool for student-faculty and student-student communications among pharmacy students and faculty in six Iraqi public schools and colleges of pharmacy. ${ }^{19}$

Despite the popularity of using Facebook ${ }^{\circledR}$ for academic purposes among health professional education programs in general and pharmacy programs in particular, ${ }^{15,20}$ information is lacking on the general perception of Facebook ${ }^{\circ}$ as a student- driven e-learning tool among pharmacy students. All previous studies were connected to pharmacy-related courses and tried to investigate the role of utilizing Facebook ${ }^{\circ}$ in achieving the learning outcomes of those courses. ${ }^{15,16,21}$ Furthermore, these studies focused on formal, instructor-driven approaches of using Facebook in teaching/learning rather than investigating the students self-use of Facebook for academic purposes. This study aims to investigate the general pattern of using Facebook ${ }^{\circ}$ among pharmacy students at JUST and their attitude towards its use for teaching and learning purposes.

\section{METHODS}

This study was a descriptive cross-sectional questionnairebased survey. A 38-item questionnaire was developed through a multi-step iterative process to achieve the objectives of the study. First, an extensive review of available literature was conducted to develop the initial draft of the questionnaire. ${ }^{13,22,23}$ Second, a panel of three pharmacy faculty members with expertise in pharmacy practice and education research performed a content validation of the developed questionnaire to ensure clarity of language, comprehension of questions to achieve study objectives, and natural flow of questions. Third, an online version of the questionnaire was designed and uploaded to SurveyPlanet ${ }^{\circ}$, a professional website for developing online surveys (SurveyPlanet, LLC, Los Angeles, CA). Finally, the questionnaire was piloted among 10 pharmacy students to assess its clarity and comprehension. Accordingly, several modifications were applied using an iterative process at different stages of questionnaire development before the final version emerged. The questionnaire was developed in English language, the official language of study at JUST.

The questionnaire items were close-ended and fall under four different sections: (1) socio-demographic and professional characteristics (11 items); (2) general pattern of using Facebook $^{\circ}$ (9 items); (3) Facebook ${ }^{\circ}$ use for academic purposes among pharmacy students (11 items); (4) attitudes towards the use of Facebook in pharmacy education (7 items). The survey was designed to allow individual respondents to answer only the questions that were relevant to them. For example, nonFacebook users were able to answer only the questions included in the first and the last sections of the questionnaire. The study was approved for ethical compliance by the Institutional Review Board at JUST.

The link to the final version of the online survey was sent to pharmacy students at JUST via their university e-mail, Facebook $^{\circ}$ messages, posting on Facebook ${ }^{\circ}$ groups related to pharmacy students at JUST, and other social media. Only students who started their professional years of study were targeted for participation. The survey was opened from January 1 to February 28, 2017. A reminder invitation for the 
participation was posted every two weeks to enhance the response rate. The survey was anonymous, and no one would be able to link the participants with their respective responses. Over the period of two months, the responses received were regularly reviewed and responses provided by ineligible individuals (e.g. non-pharmacy students, or non-student pharmacists) were excluded from data analysis by using several of the demographic questions for filtering.

The Statistical Package for Social Sciences, version 22 (IBM SPSS $^{\circledast}$ Statistics for Windows; IBM Corp, Armonk, New York, USA) was utilized for the analyses of the data collected. Frequencies and percentages were predominantly used to present and summarize the data generated through this study.

\section{RESULTS}

Of the 2,300 pharmacy students in various professional years at JUST, 720 students responded to the survey with a corresponding response rate of $31.3 \%$. The majority of the respondents were female (83.6\%), single (96\%), Jordanian $(87.4 \%)$ students with age that ranges from $18-25$ years (98.6\%). (Supplemental file Table 1). Similar proportions of BSc Pharmacy and PharmD students responded to the survey (48.2\% vs. $51.8 \%$, respectively). Most of the respondents (61.9\%) have an overall grade average that ranges between good and very good. (Supplemental file Table 2)

The vast majority (98.8\%) of pharmacy students who responded had personal accounts on Facebook ${ }^{\circledR}$, and $94 \%$ of them were using smartphones to access it, mainly through the application version of Facebook ${ }^{\star}(93.4 \%)$. In general, most respondents created their Facebook ${ }^{\circledR}$ accounts more than five years ago (60.9\%), usually browse their Facebook ${ }^{\circledR}$ several times a day (86.2\%), and spent $1-3$ hours per day on Facebook (44.9\%). Home or hostel was the most frequently (66.9\%) reported browsing area for Facebook ${ }^{\circledR}$ users. At the university, only $15.8 \%$ of Facebook ${ }^{\star}$ users reported browsing their Facebook ${ }^{\circ}$ accounts in the classroom setting during lectures (Supplemental File Table 3). Facebook was reported by its users to be an alternative to: e-mails (58\%), traditional phone calls (37.5\%), Dropbox (30.5\%), Google Drive (26.9\%), and other tools. The majority of respondents (82.4\%) reported that they used Facebook ${ }^{\star}$ for studying or academic purposes, besides using it to be in contact with classmates $(73.0 \%)$, friends and/or family (71.4\%), and to keep up to date with news and events (63.0\%). (Supplemental File Table 4)

Table 1 summarizes the general trend of utilizing Facebook ${ }^{\circledR}$ for academic purposes among the respondents. A large proportion of the pharmacy students reported that they used Facebook ${ }^{\circledR}$ for studying purposes, to communicate with other faculty members, and to join Facebook studying groups. Overall, respondents reported that the characteristics of
Facebook made it a useful tool for studying. The most frequently reported features used by the respondents when they utilized Facebook ${ }^{\circledR}$ for academic and studying purposes included the ability to upload files (72.5\%), share information with others $(70.3 \%)$, and the opportunity to create or participate in groups (63\%).Some limitations that need further improvement, such as inability to share big files and limited privacy and security, are reported in Table 2.

Most respondents demonstrated a general positive attitude toward the use of Facebook ${ }^{\circledR}$ in pharmacy education (Table 3). The largest proportion of respondents believed that Facebook ${ }^{\circ}$ contributed to their academic success, and would recommend Facebook ${ }^{\circledR}$ as a studying tool to other students and friends.

\section{DISCUSSION}

This study investigates the use of Facebook ${ }^{\circledR}$ for teaching and learning purposes among pharmacy students in the Middle East region, and reports its usefulness as an informal and formal e-learning tool in academic settings.

The use of Facebook ${ }^{\circledR}$ was highly prevalent among pharmacy students in Jordan. This finding was similar to those reported among students of other healthcare professions. ${ }^{22,24,25}$ Specifically, $88 \%$ of students from 23 different Saudi Arabian medical schools were using social media in their education, and Facebook ${ }^{\circ}$ was the second most commonly used social media platform for medical education after Youtube ${ }^{26}$ Despite the widespread use of Facebook ${ }^{\circledR}$ among pharmacy students, only $23 \%$ of respondents admitted to browsing Facebook ${ }^{\circledR}$ at the university, and a smaller proportion of those $(16 \%)$ were browsing it in classrooms during lectures. This suggests that Facebook may not necessarily be a source of distraction for students during lectures and may not have a profound negative effect on their academic performance. Moreover, this indicates that students are using Facebook ${ }^{\circledR}$ when they are a distance from the university and feel comfortable at home; a major advantage of e-learning systems over the traditional learning approaches.

This study addressed the unique experience of pharmacy students at JUST, who were able to create and control their own e-learning environment within a social media site, such as Facebook $^{\circ}$. It is worth mentioning that each cohort of pharmacy students at JUST has their own Facebook ${ }^{\circledR}$ closed group in which they can communicate, run discussion sessions, and share study materials. This could explain the observed large proportion of pharmacy students (95\%) joining Facebook $^{\star}$ studying groups. Other evidence for the unique Facebook ${ }^{\top}$ learning experience at JUST is that more than half of the respondents had used Facebook ${ }^{\circledR}$ as an alternative to email. While university e-mail is the official or formal way of communication between students and faculty members 
according to JUST academic policies, we noticed that students were much more receptive to fill the questionnaire when contacted through Facebook ${ }^{\star}$ messenger and Facebook ${ }^{\star}$ studying groups than through their university e-mail. A similar finding was reported in Iraqi schools of pharmacy, where both students and faculty use Facebook ${ }^{\circledR}$ more than university email for academic communications. ${ }^{19}$

Two-thirds of the respondents found Facebook ${ }^{\circledR}$ a useful way to communicate with their instructors. Only $3 \%$ of the respondents did not have any teacher available on their Facebook ${ }^{\circledR}$, which suggests that most faculty members at JUST pharmacy school have their Facebook personal accounts and accept the communication with students through this social media tool. Some could argue that most faculty members are less likely to accept Facebook ${ }^{\circledR}$ as a scholarly e-learning tool to protect the privacy and confidentiality of their social life. However, Facebook ${ }^{\circledR}$ group and messenger systems allow members to interact and communicate without a need to be Facebook ${ }^{\star}$ friends. This could successfully protect the social privacy of both teachers and students. The popularity of using Facebook $^{\otimes}$ among pharmacy educators was reported previously, where $65 \%$ of five pharmacy school's faculty members in the US were using Facebook ${ }^{\oplus}$, and half of them were likely or very likely to use Facebook ${ }^{\star}$ in the teaching process. $^{27}$

University e-learning systems require students to register via username and password to access their page or the portal in general. The course coordinator is the only authorized person who is able to download materials, post assignments and quizzes, and control the discussions. Through the formal elearning tools, students can only communicate with the course coordinator and students registered in the course. Communication with previous course students is nearly impossible. In contrast, Facebook ${ }^{\circledast}$ has the fluidity and flexibility to be utilized as a student- or instructor-driven platform, or both. This shared authority between students and educators in controlling Facebook ${ }^{\circledR}$ academic groups could help to overcome most of the previously mentioned drawbacks of formal instructor-driven e-learning tools. Facebook ${ }^{\circledR}$ learning groups can be easily created and controlled by either students or educators. In addition, Facebook ${ }^{\circledR}$ group allows for deciding the members of this group and uploading/downloading study materials in different forms, such as documents, photos, or videos. Students used studying groups for various academic purposes, such as downloading lectures and study materials, communicating with colleagues regarding academics, getting help in academic issues, providing support to other students, participating in course-related discussion, communicating with teachers and faculty members, and many others as shown in Table 1. Facebook posts that involved old quizzes, exams, and revision files were the most preferred posts among pharmacy students at JUST. Consistent with this finding, quizzes (87\%) and revision files (82\%) posts received the highest preference among medical students at the University of Ottawa. ${ }^{22} \mathrm{We}$ have observed that Jordanian pharmacy students have developed a unique culture of working together to exchange knowledge and information in course-related materials. This may sound unusual knowing that students fiercely compete among each other for the best rank. The university offers scholarships to top students and sponsor few yearly to pursue higher degrees. Such immense interaction and strong collaboration is partially explained by the fact that several active students in each cohort offer to serve their peers to win their votes during the annual college elections for student representative posts. Another reason is culturally rooted, the nature of a Jordanian is to help other fellow nationals, since many share either geographical or tribe ties.

In general, most respondents showed a positive attitude toward the use of Facebook ${ }^{\circ}$ in pharmacy education and academic settings. More than $95 \%$ found it useful or very useful for studying or academic purposes and more than $75 \%$ believed that Facebook ${ }^{\circledR}$ contributes to their academic success. However, $29 \%$ of students thought that Facebook had an overall negative impact on students' academic performance, with $38 \%$ having a neutral position toward this statement. Respondents might not have differentiated between modest and excessive use of Facebook ${ }^{\circledR}$. Excessive use of Facebook ${ }^{\circ}$ and other social media tools is known to cause addiction, could negatively affect students' social life and academic performance, and could cause various health problems. ${ }^{24,28}$ Therefore, despite the usefulness of Facebook ${ }^{\circledR}$ in academic settings, students should try to control the time they spend on this social media platform. Students could minimize that time spent on Facebook ${ }^{\circ}$ by reducing the personal uses of Facebook ${ }^{\circledR}$, such as entertainment or chatting with friends.

Although this study addressed the ability of students to create their own informal e-learning platform on Facebook ${ }^{\circledR}$, we believe that formal endorsement by colleges and administration would further improve the efficiency of utilizing Facebook $^{\star}$ in academic settings. This will potentially open the door for more efficient communications between faculty and students. For instance, faculty members could use Facebook ${ }^{\circledR}$ to provide students with feedback on the general discussion of topics, to answer students' questions, or to make immediate announcements, as students rarely miss checking their academic Facebook ${ }^{\circledR}$ groups. However, the strategy of creating a formal instructor-driven learning platform on Facebook ${ }^{\circledR}$ needs further investigation. The acceptability of using this social media tool for studying and learning purposes may depend on students' culture, familiarity with using Facebook ${ }^{\circledR}$, and their general trend of using Facebook ${ }^{\circledR}$ for studying purposes. Furthermore, issues related to privacy and 
e-professionalism should be adequately addressed before formally implementing Facebook ${ }^{\circ}$ and other social media tools. ${ }^{29}$ Although Facebook provides students with a friendly environment to communicate, showing mutual respect is required when communicating with colleagues and instructors via Facebook ${ }^{\circ}$. Sharing personal and social-life related information should also be avoided on Facebook study groups. Both, students and faculty members should be able to differentiate between their informal personal profiles on Facebook $^{\circ}$ and the semi-formal academic groups on Facebook $^{\circ}$. The mixed informal and formal nature of Facebook ${ }^{\circ}$, when used for academic purposes, helps students to build friendship with their instructors that may extend even after graduation. However, close friendship between students and instructor have its disadvantages too, and should be dealt with caution.

The current study has contributed additional information to the existing literature. However, this study has some limitations. First, the response rate of $31 \%$ among pharmacy students at JUST may appear to be inadequate. Nevertheless, the sample of students who responded is representative of the population of pharmacy students at JUST, as demonstrated by respondent demographics. Second, participants' responses to attitude questions are subject to social desirability bias, and the findings should be interpreted with caution. Third, the questionnaire was anonymous, so those who responded more than once, if any, could not be identified. Fourth, feedback from those who were not inclined to respond to an electronic survey could not be captured. Finally, although the study was conducted at the largest pharmacy school in Jordan, the generalizability of findings is limited inside and outside Jordan.

\section{CONCLUSIONS}

The results of this study help pharmacy educators to understand how and why students use Facebook ${ }^{\circ}$, their major needs, and the limitations of using social media in learning environments.

In addition, the findings of this study support the use of Facebook $^{\circ}$ as an alternative to formal e-learning management systems to enhance students' performance, facilitate the conduct of discussion sessions outside the classroom, and allow for easy communication between students themselves or between students and their educators. Facebook ${ }^{\circ}$ adoption as an e-learning platform may be a particular asset when universities and colleges could not have access to formal elearning management systems (such as Blackboard or Canvas), when the existing e-learning system does not meet students' needs, or when users believe that Facebook ${ }^{\circ}$ would further support a learning management system. The study highlights the unique added value of students to communicate amongst and learn from each other. Universities and educational institutions should make efforts to create appropriate learning environments within Facebook ${ }^{\circ}$ that could meet students' educational needs and positively enhance their academic success. Furthermore, this information can help in developing various strategies to formally implement Facebook ${ }^{\circ}$ and other social media platforms as e-learning tools within an educational context. In countries with limited resources, Facebook ${ }^{\circ}$ could be a promising educational platform that would be very handy and affordable for both students and educators, and would provide various features that are comparable to other formal e-learning tools.

\section{Disclosures: None}

\section{REFERENCES}

1. Rowe M, Frantz J, Bozalek V. The role of blended learning in the clinical education of healthcare students: a systematic review. Medical teacher. 2012;34(4):216221. doi: 10.3109/0142159X.2012.642831.

2. Back DA, Behringer $F$, Sostmann $K$, Peters $H$, Haberstroh $N$, Ehlers JP. Learning management system and elearning tools: An experience of medical students' usage and expectations. International Journal of Medical Education. 2016;7:267-273. doi: 10.5116/ijme.57a5.fof5.

3. 20 colleges making good use of social media 2011. USA Today Educate Web Site.

http://www.usatodayeducate.com/staging/index.php/t he-20-colleges-making-the-best-use-of-socialmedia. Accessed February 28, 2018.

4. Gray K, Annabell L, Kennedy G. Medical students' use of Facebook to support learning: insights from four case studies. Medical teacher. 2010;32(12):971-976. doi: 10.3109/0142159X.2010.497826.

5. Davis WM, Ho K, Last J. Advancing social media in medical education. Canadian Medical Association Journal. May 19 2015;187(8):549-550. doi: 10.1503/cmaj.141417.

6. Grindrod K, Forgione A, Tsuyuki RT, Gavura S, Giustini D. Pharmacy 2.0: A scoping review of social media use in pharmacy. Research in Social and Administrative Pharmacy. 2014;10(1):256-270. doi: 10.1016/j.sapharm.2013.05.004.

7. Knautz K, Baran KS. Facets of Facebook : use and users. Berlin: De Gruyter, 2016. Open access (Ebook). ISBN 978-3-11-041816-3.

8. Facebook Stats 2017. Facebook Newsroom Web Site. https://newsroom.fb.com/company-info/. Accessed February 28, 2018. 
9. Ophus JD, J.T. A. Exploring the potential perceptions of social networking systems in university courses. Journal of Online Learning and Teaching. December 2009;5 (4).

10. elwyn N. Faceworking: Exploring students' educationrelated use of Facebook. Learning, Media and Technology. 2009;34(2):157-174.

11. Ali A. Medical students' use of Facebook for educational purposes. Perspectives on Medical Education. Jun 2016;5(3):163-169.

12. Valova I. Facebook or Learning Management System. International Conference on e-Learning'15. 2015.

13. Pickering JD, Bickerdike SR. Medical student use of Facebook to support preparation for anatomy assessments. Anatomical Sciences Education. Jun 2017;10(3):205-214. doi: 10.1002/ase.1663.

14. Pinilla S, Nicolai L, Gradel M, et al. Undergraduate Medical Students Using Facebook as a Peer-Mentoring Platform: A Mixed-Methods Study. JMIR Medical Education. Oct 27 2015;1(2):e12. doi: 10.2196/mededu.5063

15. DiVall MV, Kirwin JL. Using Facebook to facilitate courserelated discussion between students and faculty members. American journal of pharmaceutical education. 2012;76(2). doi: 10.5688/ajpe76232.

16. Estus EL. Using facebook within a geriatric pharmacotherapy course. American journal of pharmaceutical education. 2010;74(8).

17. Cain J, Policastri A. Using Facebook as an informal learning environment. American journal of pharmaceutical education. 2011;75(10).

18. Ryan. GJ, Augustine. J. Use of Class Facebook Groups to Disseminate Evidence-Based Study Tips. Innovations in Pharmacy. 2017;8(3).

19. Al-Jumaili AA, Al-Rekabi MD, Alsawad OS, et al. Exploring Electronic Communication Modes Between Iraqi Faculty and Students of Pharmacy Schools Using the Technology Acceptance Model. American journal of pharmaceutical education. 2017;81(5). doi:10.5688/ajpe81589.

20. Cain J, Scott DR, Akers P. Pharmacy students' Facebook activity and opinions regarding accountability and eprofessionalism. American journal of pharmaceutical education. Oct 01 2009;73(6):104.
21. Benetoli A, Chen TF, Aslani P. The use of social media in pharmacy practice and education. Research in Social and Administrative Pharmacy. 2015;11(1):1-46. doi: 10.1016/j.sapharm.2014.04.002

22. El Bialy S, Jalali A. Go Where the Students Are: A Comparison of the Use of Social Networking Sites Between Medical Students and Medical Educators. JMIR medical education. 2015;1(2):e7.

23. Donlan L. Exploring the views of students on the use of Facebook in university teaching and learning. Journal of Further and Higher Education. 2014;38(4):572-588.

24. Jha RK, Shah DK, Basnet S, et al. Facebook use and its effects on the life of health science students in a private medical college of Nepal. BMC research notes. 2016;9. doi: 10.1186/s13104-016-2186-0

25. Gafni R, Deri M. Costs and benefits of Facebook for undergraduate students. Interdiscip. J. Inf. Knowl. Manage. Interdisciplinary Journal of Information, Knowledge, and Management. 2012;7:45-61.

26. Alsuraihi AK, Almaqati AS, Abughanim SA, Jastaniah NA. Use of social media in education among medical students in Saudi Arabia. Korean Journal of Medical Education. Dec 2016;28(4):343-354. doi: 10.3946/kjme.2016.40

27. Cain J, Scott DR, Tiemeier AM, Akers P, Metzger AH. Social media use by pharmacy faculty: Student friending, e-professionalism, and professional use. Currents in Pharmacy Teaching and Learning. 2013;5(1):2-8. doi.org/10.1016/j.cptl.2012.09.002

28. 2Guedes E, Sancassiani F, Carta MG, et al. Internet Addiction and Excessive Social Networks Use: What About Facebook?. Clinical practice and epidemiology in mental health. 2016;12:43-48. doi: 10.2174/1745017901612010043.

29. Chisholm-Burns MA, Spivey CA, Jaeger MC, Williams J, C. G. Development of an instrument to measure pharmacy student attitudes toward social media professionalism. American Journal of Pharmaceutical Education2017;81(4). doi:10.5688/ajpe81465 
Table 1: Utilization of Facebook among Pharmacy Students for Academic Purposes $(n=711)$

\begin{tabular}{|c|c|}
\hline Variable & $\begin{array}{l}\text { Students } \\
\mathrm{n}(\%)\end{array}$ \\
\hline \multicolumn{2}{|l|}{ Facebook usage for academic purposes* } \\
\hline I do not use Facebook for academic purposes & $33(4.6)$ \\
\hline To communicate with colleagues in pharmacy school regarding academics & $571(80.3)$ \\
\hline To communicate with teachers and faculty members in pharmacy school regarding academics & $332(46.7)$ \\
\hline To download lectures and study materials & $626(88.0)$ \\
\hline To arrange for university extracurricular activities & $294(41.4)$ \\
\hline To get help in academic issues (e.g, homework, reports) & $475(66.8)$ \\
\hline To provide support for other students (e.g. sharing your experience) & $379(53.3)$ \\
\hline To participate in a course-related discussion between students and faculty members & $296(41.6)$ \\
\hline To participate in Facebook groups to prepare for exam & $370(52.0)$ \\
\hline To share online materials with other students & $385(54.1)$ \\
\hline To keep updated with college and courses announcements & $449(63.2)$ \\
\hline Other academic purposes & $2(0.3)$ \\
\hline \multicolumn{2}{|l|}{ Successful communication with faculty member } \\
\hline Yes & $474(66.7)$ \\
\hline No & $216(30.4)$ \\
\hline My teachers aren't available on Facebook & $21(3.0)$ \\
\hline \multicolumn{2}{|l|}{ Preferred educational posts on Facebook* } \\
\hline Old quizzes and exams files & $537(75.5)$ \\
\hline Revision files & $429(60.3)$ \\
\hline Explanatory comments & $321(45.1)$ \\
\hline Post-lecture questions & $341(48.0)$ \\
\hline Course-related humor & $251(35.3)$ \\
\hline Book/article recommendations & $306(43.0)$ \\
\hline Videos & $322(45.3)$ \\
\hline None & $12(1.7)$ \\
\hline Other types of educational posts & $4(0.6)$ \\
\hline \multicolumn{2}{|l|}{ Facebook studying group(s) joined } \\
\hline Yes & $675(94.9$ \\
\hline No & $22(3.1)$ \\
\hline I am not aware of such group(s) & $8(1.1)$ \\
\hline There is no such studying group(s) & $6(0.8)$ \\
\hline \multicolumn{2}{|l|}{ Faculty/University Facebook pages followed* } \\
\hline The official Facebook page for pharmacy faculty & 639 (89.9) \\
\hline The official Facebook page for the university & $570(80.2)$ \\
\hline Other non-official university-related pages & $354(49.8)$ \\
\hline None & $14(2.0)$ \\
\hline \multicolumn{2}{|l|}{ Facebook usefulness for studying or academic purposes } \\
\hline Very useful & $455(64.0)$ \\
\hline Somewhat useful & $233(32.8)$ \\
\hline Not very useful & $20(2.8)$ \\
\hline Absolutely not useful & $3(0.4)$ \\
\hline
\end{tabular}

*Question allows for multiple responses 
Table 2: The Most Useful Features of Facebook for Studying Purposes $(n=711)$

\begin{tabular}{ll}
\hline Variable & Students \\
& $\mathbf{n}(\%)$ \\
\hline Facebook features that are used for studying purposes* & $447(63.0)$ \\
Creating or participation in groups & $347(48.9)$ \\
Chatting & $515(72.5)$ \\
Uploading files & $199(28.0)$ \\
Making appointments & $499(70.3)$ \\
Sharing information & $24(3.4)$ \\
None & $4(0.6)$ \\
Other features & $588(82.7)$ \\
Facebook features that make it a useful tool for academic purposes* & $491(69.1)$ \\
Ability to reach all colleagues in a single group & $521(73.3)$ \\
Quick response to comments & $538(75.7)$ \\
Benefit of reading other students comments and posts & $339(47.7)$ \\
Ease of asking questions & $15(2.1)$ \\
Familiarity and informality of format & $3(0.4)$ \\
None & \\
Other useful features & $10(1.4)$ \\
\hline
\end{tabular}

*Question allows for multiple responses 
Table 3: The General Attitudes of Pharmacy Students in Jordan Toward the Use of Facebook in Pharmacy Education and Practice $(n=720)$

\begin{tabular}{|c|c|c|c|c|c|}
\hline Attitudinal statement & $\begin{array}{l}\text { Strongly Agree } \\
\text { N (N \%) }\end{array}$ & $\begin{array}{l}\text { Agree } \\
\text { N (N \%) }\end{array}$ & $\begin{array}{l}\text { Neutral } \\
\text { N (N \%) }\end{array}$ & $\begin{array}{l}\text { Disagree } \\
\text { N (N \%) }\end{array}$ & $\begin{array}{l}\text { Strongly } \\
\text { Disagree } \\
\text { N (N \%) }\end{array}$ \\
\hline $\begin{array}{l}\text { I believe that Facebook } \\
\text { contributes to my academic } \\
\text { success* }\end{array}$ & $225(31.6)$ & $334(47.0)$ & $125(17.6)$ & $25(3.5)$ & $2(0.3)$ \\
\hline $\begin{array}{l}\text { I would recommend } \\
\text { Facebook as a studying tool } \\
\text { to other students or friends } \\
\text { of mine* }\end{array}$ & $205(28.8)$ & $328(46.1)$ & $149(21.0)$ & $27(3.8)$ & $2(0.3)$ \\
\hline $\begin{array}{l}\text { Overall, Facebook has } \\
\text { negative effects on students' } \\
\text { academic performance }\end{array}$ & $65(9.0)$ & $144(20.0)$ & $272(37.8)$ & $147(20.4)$ & $90(12.5)$ \\
\hline $\begin{array}{l}\text { Facebook is a source of } \\
\text { inspiration and motivation } \\
\text { for students' learning }\end{array}$ & $104(14.5)$ & $275(38.4)$ & $203(28.4)$ & $100(14.0)$ & $30(4.2)$ \\
\hline $\begin{array}{l}\text { Pharmacy students should } \\
\text { try to reduce the time they } \\
\text { spend on Facebook }\end{array}$ & $197(27.5)$ & $205(28.6)$ & $182(25.4)$ & $80(11.2)$ & $43(6.0)$ \\
\hline $\begin{array}{l}\text { Facebook is considered as a } \\
\text { useful studying tool for } \\
\text { pharmacy students }\end{array}$ & $139(19.4)$ & $311(43.4)$ & $174(24.3)$ & $64(8.9)$ & $23(3.2)$ \\
\hline $\begin{array}{l}\text { Facebook is well accepted in } \\
\text { teaching and learning } \\
\text { environments }\end{array}$ & $115(16.1)$ & $280(39.1)$ & $202(28.2)$ & 86 (12.0) & $29(4.1)$ \\
\hline $\begin{array}{l}\text { Faculty of pharmacy should } \\
\text { encourage students to use } \\
\text { Facebook for academic } \\
\text { purposes }\end{array}$ & 139 (19.4) & $248(34.7)$ & $215(30.1)$ & $80(11.2)$ & $32(4.5)$ \\
\hline $\begin{array}{l}\text { Support from academic } \\
\text { leadership is required for the } \\
\text { successful use of Facebook } \\
\text { as a platform for teaching } \\
\text { and learning }\end{array}$ & $140(19.7)$ & $238(33.4)$ & $251(35.3)$ & $52(7.3)$ & $31(4.4)$ \\
\hline
\end{tabular}

